\title{
Project-Based Learning in the Aspect of Forming the Professional Identity of Engineering Major Students
}

\author{
Aleksey Dorofeev ${ }^{1}$, Galina Bukalova ${ }^{2},{ }^{*}$ Alexander Novikov ${ }^{2}$ \\ ${ }^{I}$ National Research University Higher School of Economics, Financial University under the Government of the \\ Russian Federation, Russia \\ ${ }^{2}$ Orel state university named after I.S. Turgenev, Russia \\ *Email: 57orleya@gmail.com
}

\begin{abstract}
Within the post-industrial society, Russian engineering training faces a topical pedagogical issue of forming professional identity by students as the main element of professional responsibility of engineering professionals. The purpose of this article is bringing the specifics of forming professional identity by students to the current discourse of researchers of the issues of engineering training. We have researched the level of topic relevance of the engineering graduate competences declared to be mastered at Turgenev Orel State University. 69 managers and experts of 12 most competitive motor vehicle service enterprises of the Orel region (Russia) were the experimental respondents. The results revealed that the key stakeholders mainly acknowledge the topical relevance of university graduate competencies, which forms a basis of their professional identity connected to their major. The article offers a set of scientific and pedagogical provisions encouraging the college training process to focus on forming the professional identity of their students. The authors have proven the reasonability of using the project-based learning model to form a professional identity. They have also developed the layout of the training models set to form a didactic core of project-based classes focused on forming a professional identity of students. The approach developed by the authors can be applied to the training process of both engineering and other majors.
\end{abstract}

Keywords: Post-industrial society, Professional identity, Engineering training, Project-based learning, Teaching models.

\section{INTRODUCTION}

The development of post-industrial society guides the organisation and process changes of the Russian motor transport industry branch. Within the post-industrial society, the change of traditionally centralised type of motor transport industry appears to be a replacement of centralisation to the autonomy [1]. According to the forecast of a renowned sociologist D. Bell, post-industrial society faces an "inevitable shift toward the free and responsible individual actions" [2]. In this regard, the issue of professional responsibility for the process and the result of the production activity become topical. Professional responsibility is acknowledged to be one of the main features of the labour force of post-industrial production era [3,4].
The concept of professional responsibility inherent to post-industrial production implies focusing engineering training on forming a professional identity of university students. The level of professional identity maturity corresponding to the conditions of the post-industrial production process "...demands not only to implement information technologies into the training course but to create a new methodological training basis" [5]. Professional identity and students mastering of the values and senses of future labour activity is based on the full implementation of activity position during the training process in the university. Project-based learning implemented into the training courses for engineering majors serves as the means to solve this task $[6,7,8]$. 


\section{RESEARCH METHODOLOGY}

Within the current conditions of emerging postindustrial society, motor transport production complex faces a new form of requirements for a particular type of morality and worldview of engineers and service experts creating the basis of personnel professional identity. The concepts of model psychological and pedagogical researches claim professional identity to be the main feature of a person's professional growth [9,10,11]. Specifically, E.P. Yermolayeva offers a detailed description of professional genesis [8]. According to this concept, forming of professional identity is related to the change of a person's view of himself or herself as a subject of professional activity. This thesis allows concluding the transforming function of professional identity. It is a relevant phenomenon for the university training process.

Professional identity as a topical phenomenon is discussed in modern works on labour psychology. In the context of labour psychology, professional identity is described as an integrative psychological phenomenon, a dominant component of a personality, serving for selfdetermination and professional growth of the labour subject. This phenomenon is acknowledged to be formed with the help of professional aptitude, professional readiness and professional self-comprehension. E.A. Klimov approaches professional identity as "a certain systemic arrangement of consciousness and psychic setup" [12]. The researcher described the structure of professional identity (calling it "professional selfcomprehension") as a combination of awareness of belonging to a specific professional community, understanding the need to comply with the professional behaviour standards, striving towards recognition in a professional group, and a future perspective of oneself and one's work. A sufficient level of professional identity formation, as E.A. Klimov states it, makes an employee "integrated, identified and determined" [12]. L.B. Schneider claims that a positive attitude of a person to the profession is a necessary precondition for professional identity formation [13]. There are other important factors for professional identity formation as a sign of belonging to a professional community except for professional activity requirements [14]. Another critical factor is mastering the traditional communication principles of professional society $[15,16]$.

Turgenev Orel State University is an essential university supplying engineering and service experts to motor vehicle enterprises in the Orel region. We have researched to define the level of topical relevance of the educational goals - competences of motor transport graduates (Chair of Vehicles Service and Repair) majoring in Operation of Transport and Process Machines and Complexes declared by the university [17]. The research method of choice was expert poll questioning. One generation of respondents was formed out of the leading experts and directors of 12 competitive motor vehicle enterprises in the Orel region. Undergraduate and graduate students of Polikarpov Polytechnic Institute of Turgenev Orel State University formed the second generation of respondents. A methodological basis for the research was a competence approach. The study included an analysis of the level of respondent acknowledgement of the topical relevance of 46 training practices (university graduate competences). The aggregate of the analysed competences was structured the same way as SDIO Syllabus architecture [18].

\section{RESEARCH RESULT}

The questioning underwent a quantitative analysis using a 100-point assessment scale. You can find the level of respondent acknowledgement of the topical relevance of competence group Professional Competencies and Personal Traits (fragment of the research result) in table 1.

Questioning and poll of practising respondents yielded unexpected results. Practising respondents found quite different competences to be the most relevant and to signal the readiness to direct engineering operation activities. Specifically, they emphasised the competencies are demonstrating the types of professional responsibility in the context of moral and ethical notions; readiness to analyse engineering solutions in the context of professional responsibility; ability to solve process issues exhibiting a high level of independence. Research results allowed us concluding that the revealed complex

Table 1. Competences topical relevance of engineering experts of motor vehicle service enterprise

\begin{tabular}{|l|c|c|}
\hline \multicolumn{1}{|c|}{ Group of the analysed educational goals } & $\begin{array}{c}\text { Assessment of practicing experts } \\
\text { (grades) }\end{array}$ & $\begin{array}{c}\text { Assessment of } \\
\text { students (grades) }\end{array}$ \\
\hline Analytical feasibility and solution of process issues & 83.08 & 81.29 \\
\hline & & 67.02 \\
\hline Experiment and research & 62.46 & 62.29 \\
\hline Systematic character of professional thinking & 73.08 & 49.45 \\
\hline Civil and worldview position, cognition & 56.23 & 61.05 \\
\hline Ethics, justice and professional responsibility & 95.38 & \\
\hline
\end{tabular}


of competences corresponds to the notion of professional identity (from the labour psychology thesaurus [12]). We have identified a focus on a new pedagogical issue creating training conditions in which university students can form a professional identity as motor transport engineering experts.

Scientific relevance of the mentioned pedagogical issue is justified by a high level of acknowledgement of topical competences (training practices) as a basis of the university graduates professional identity by regional profile business community, and lack of actual pedagogical activities models directed on forming the engineering students professional identity. In the pedagogical practice of engineering universities, forming of the professional identity of students is usually not set as a high order educational goal $[19,20]$. A traditional training process of engineering students focuses on mastering knowledge and operational skills. However, it is also essential for engineering universities to instil important personal traits in graduates in professional terms. The set of such traits forms professional identity. Professional identity is a comprehensive educational goal. In this regard, organisation of training process focused on forming professional identity by students implies a complex of scientific and pedagogical provisions primary related to practical pedagogical activity, with a justified choice of the relevant pedagogical technology.

\section{RESULTS DISCUSSION}

The questioning underwent a quantitative A successful formation of professional identity is preconditioned by a person understanding his or her professional features and requirements of the professional circle $[21,22,23]$. University graduate has a sufficient level of professional identity formation if he or she is aware of the need to adequately assess his or her professional features and analyse the requirements of the social professional environment. Professional identity is formed over time in line with professional growth [24]. However, the formation is initiated during university training. If a university graduate is unaware of his or her own professional identity, it poses a clear threat in terms of efficiency of his or her future professional activity.

We have developed the layout of the training models set to form a didactic core of project-based classes focused on forming the professional identity of students (using a concept of context learning proposed by A.A. Verbitsky). The semiotic model offers a structural composition and explains interrelations between crossdisciplinary theoretical provisions which serve as the basis of a study project $[25,26]$. Within this training model, students' training activities include mastering the theoretical provisions of the related courses. At that, the students master the profile production domain within the context of the study professional problem. The semiotic model approach aims at forming the cognitive component of students' professional identity. Imitation model is a means of adding the context of profile production activities to the training activities [27]. This model is implemented as a detailed and realistic description of a production problem, and the students are offered to make a study project to solve it. Student's actions imply the analysis of the process situation, articulating a problem, choosing a process and technical solution of the revealed problem considering the necessary production resources and economic feasibility. Imitation model is aimed at forming the operational component of a student's professional identity corresponding to his or her future professional activities and introducing him or her as a subject of professional activities.

Social teaching model implies creating the conditions of training where students can analyse possible social consequences of the implementation of the process and the technical decision made [28]. It allows for solving the issue of forming the responsibility of engineering experts as a component of professional identity. At this stage of professional identity formation, students acquire a new status - that of subjects of social and cultural activity. During the agreed collective work on the project, the students integrate themselves into the system of subjectto-subject professional relations. This way, they master professional communication as a component of professional identity.

Authors use the proposed didactic basis to prepare practical classes in Technical Regulation of Transport Processes for second-year master students majoring in Transport Process Technology. Before proceeding to the study project, students get recommendations on arranging the project activities. Master students are offered to break into workgroups of three or four. They independently define the deadline for study project presentation. Students shall define the structure of the study project work and elect group members responsible for project-specific elements. A critical analysis of the project elements shall be conducted. While working on project elements, students shall define its comprehensive content. Then the project shall be designed. Finally, students prepare the study group project presentation and discuss it in class.

\section{CONCLUSION}

The conducted research allows us to conclude that engineering students shall form professional identity during university training as the main component of professional responsibility, a top-priority trait of motor transport engineering experts. The results of the conducted research were used as materials to define the pedagogical concept of training process organisation at engineering faculties focused on the students forming professional identity - the concept of project-based learning. The factors for professional identity formation, 
such as requirements for operational process activities and interactions during the labour process, may be implemented by applying a project-based learning approach. In motor transport production complex, process project professional activity is deemed to be the most advanced method. Project-based training process implies an adequate environment where students may form professional identities during mastering the process project method of production.

In the context of training process focusing on professional identity-forming, it seems reasonable to apply a group study project method in universities. It allows for forming such structural elements of the professional identity as business cooperation in a workgroup aimed at solving process training problems; awareness of belonging to a professional social circle, need to comply with specific professional ethical regulations; awareness of personal and collective responsibility; mastering of professional operational duties as an engineering expert conducting process project activities $[25,26]$.

Work on process projects with obligatory implementation of analysis and reflection provides for the necessary conditions for engineering students to form a professional identity. The structural arrangement of project-based learning model described in the research serves as a reliable didactic basis to direct the training process towards the formation of professional identity as an internal resource of engineering graduates preconditioning their future professional advancement.

\section{REFERENCES}

[1] A. Kosyakov, U. Svit, S. Sejmur, S. Bimer. System engineering: Principles and practice, DMK-Press, 2014.

[2] D. Bell, The coming post-industrial society, Experience of social forecasting, Akademiya, 2004.

[3] L.L. Bucciarelli, Ethics and Engineering Education, European Journal of Engineering Education 33(2) (2018) 141-149. DOI: https://doi.org/10.1080/03043790801979856

[4] J. Dempsey, Moral Responsibility, Shared Values, and Corporate Culture. Business Ethics Quarterly 25(3) (2015) 319-340. DOI: https://doi.org/10.1017/beq.2015.31

[5] V. Testov, Information society: transition to a new paradigm of education, Pedagogy 4 (2012) 3-10.

[6] A. Verbitsky, O. Larionova, Personal and competence approaches in education: problems of integration, Logos, 2009.

[7] G. Ilyin, Projective training. Research centre for quality problems in training specialists, 1998.
[8] E. Ermolaeva, Professional identity as a complex characteristic of compliance of the subject and activity. Psychological review 2 (1998) 35-40.

[9] Yu. Povarenkov, Psychological content of the professional development of a person, Publishing URAO, 2002.

[10] N. Pryazhnikov, Theory and practice of professional self-determination, MGPPI, 1999.

[11] E. Erikson, Identity: Youth and crisis, Progress, 1996.

[12] E. Klimov, Psychology of professional selfdetermination, Academy, 2004.

[13] L. Schneider, Professional identity, MOSU, 2001.

[14] O. Shinyaeva, A. Tchape, Theoretical and methodological approaches to the study of professional identification of young people, News of higher educational institutions, Volga region. Social science 4(36) (2015) 134-145.

[15] D. Zavalishina, Technique to identify a person with a profession. Psychology subject of professional activity, 2001, pp. 104-128.

[16] P. Cardona, I. Malbašić, C. Rey, Institutions, paradoxes, and compensation logics: evidence from corporate values of the largest Chinese and US companies. Asia Pacific Business Review 24(5) (2018) 602-619. DOI: https://doi.org/10.1080/13602381.2018.1491513

[17] G. Bukalova, A. Novikov, Updating of educational standards - the basis for determining changes in the content of engineering education, World of transport and technological machines 3(62) (2018) 129-160.

[18] A. Chuchalin, Modernisation of engineering education based on international CDIO standards, Engineering education 16 (2014) 14-29.

[19] D.A. Glaser-Segura, S. Mudge, C. Brătianu, I. Dumitru, Development of professional identity in Romanian business students, Education + Training, Vol. 52 Iss. 3 (2010) 198-213. DOI: doi.org/10.1108/00400911011037337

[20] G. Tomer, S.K. Mishra. Professional identity construction among software engineering students: A study in India. Information Technology \& People 9(1) (2016) 146-172. DOI: doi.org/10.1108/ITP-102013-0181

[21] R. Bretz, T. Judge, Person-organization fit and the Theory of Work Adjustment: Implications for satisfaction, tenure, and career success. Journal of Vocational Behaviour 44 (1994) 32-54. DOI: https://doi.org/10.1006/jvbe.1994.1003 
[22] N. Ivanova, Professional identity in sociopsychological research. Questions of psychology 1 (2008) 89-100.

[23] N. Perinsky, Professional identity. Encyclopaedia of the Humanities 2 (2018) 209-211.

[24] Z. Chunfang, Integrating creativity training into Problem and Project-Based Learning curriculum in engineering education, European Journal of Engineering Education 37(5) (2012) 488-499. DOI: https://doi.org/10.1080/03043797.2012.714357

[25] A. Stokes, N. Harmer, The value of 'having a go': Trialing a project-based learning activity to inform curriculum design. Journal of Geoscience Education 66(40) (2018) 278-292. DOI: https://doi.org/10.1080/10899995.2018.1509599

[26] S. Soko, Yu Chen, A. Kollasch, T. Baul, F. S. Laanan, The Effects of a Pre-engineering Projectbased Learning Curriculum on Self-efficacy Among Community College Students, Community College. Journal of Research and Practice 38 (2014) 2-10. DOI:

https://doi.org/10.1080/10668926.2014.851954

[27] R. Graham, E. Crawley. Making projects work: a review of transferable best practice approaches to engineering project-based learning in the UK. Engineering Education 5(2) (2010) 41-49. DOI: https://doi.org/10.11120/ened.2010.05020041

[28] M. Lehmann, P. Christensen, X. Du, M Thrane. Problem-oriented and project-based learning (POPBL) as an innovative learning strategy for sustainable development in engineering education. European Journal of Engineering Education 33(3) (2008) 283-295. DOI: https://doi.org/10.1080/03043790802088566 